\title{
Understanding the Gender Biases in Modern and Pre-modern Times through Mrcchakațika and Utsav
}

\author{
Prabha Shankar Dwivedi ${ }^{1}$ and Priyanka Tripathi ${ }^{2}$ \\ ${ }^{1}$ Assistant Professor of English, Department of Humanities and Social Sciences, Indian \\ Institute of Technology Tirupati. prabhas.dwivedi@iittp.ac.in \\ ${ }^{2}$ Associate Professor of English, Department of Humanities and Social Sciences, Indian \\ Institute of Technology Patna.priyankatripathi@iitp.ac.in
}

\begin{abstract}
Gender Bias is a phenomenon that strengthens in India as a result of personal values and perception, traditionally assigned roles on the basis of sex and regressive ideologies deeply entrenched in patriarchy. Vasantasenā is the protagonist of the Mrcchakațika of Sūdraka, a classical Indian masterpiece written in c. 350 BCE which was later adapted into a Hindi film-Utsav (1985) written and directed by Girish Karnad. Despite being an adaptation, in its filmy avatar, Karnad denies Vasantasenā love and respect due to her profession and resorts to endorsing the conventional whereas in the original text she is a respectable woman. The article offers a comparative study of the treatment given to courtesans in general and reflects upon their complex realities by comparing the treatment of an Indian courtesan of two historically apart periods.
\end{abstract}

Keywords: Gender Bias; Courtesan; Film Adaptation; Patriarchy; Culture

Scientific advancements and liberation from the ties of cultural institutions make us feel that we have grown much more than what we used to be; but, a close analysis clearly indicates that if we compare the literature available of both these periods, there is a clear-cut transition that has taken place. The transition has been evident in the sense that we grew from joint families to nuclear families, and further, from nuclear family to no-family, forgoing the institution of marriage, and therefore, children, and subsequently the familial and social responsibilities. A close reflection of the altered pattern makes one rethink of this paradigm shift. The discussion, in this paper, is around one such transition that is seminal to the understanding of women's position in general and a courtesan in particular in Indian societies of two historically apart periods. The paper, for comparison, relies on a classical Indian masterpiece- the Mrcchakațika of Südraka written in c. 350 BCE, and a Hindi film- Utsav, an adaptation of the Mrcchakatika, released in 1985. Further, the paper discusses about the exigencies felt by the filmmakers to change the prime theme of the narrative to deprive a courtesan of what she had been given by Südraka in the $3^{\text {rd }} / 4^{\text {th }}$ century BCE. There are numerous other films like Mughal- E-Azam (1960), Pakeezjah (1971) Umrao Jaan (1981) which despite its grandeur and strength to the character of a courtesan failed to acknowledge her position adhering to the colonial documentation in which courtesans were often referred as prostitutes (Tula and Pande, 74) and compelled to "living the life of shame" (Chandra, 13). Tripathi and Das quite contextually observe and infer that despite utilizing their professional services, our hypocrite Indian society shuns them publicly under the garb of a gentlemanly outlook playing upon the politics of "shame" (22). These women are denied the love

(C) AesthetixMS 2020. This Open Access article is published under a Creative Commons Attribution Non-Commercial 4.o International License (http://creativecommons.org/licenses/by-nc/4.o/), which permits non-commercial re-use, distribution, and reproduction in any medium, provided the original work is properly cited. For citation use the DOI. For commercial re-use, please contact editor@rupkatha.com. 
a man they desire for nothing but their being a courtesan. In almost all the cases, a courtesan's profession has not been her choice but she is denied, position and emotion only due to regressive societal pressure.

Amritlal Nagar rightly says,

"Veshyayon ke sambandh me unki ninda ke atirikta aur kuch bhi likhana aamtaur per ninda ka vishaya mana jata raha hai. Scott ne apni prasiddha pustak 'A History of Prostitution from Antiquity to the Present Day' ki bhumika me is vishaya me likhne walon ke sankoch ka itihas bhi diya hai. San 1951 me French vidwan Lecroks ne do bhago me veshya jivan ka itihas prastut to kiya, parantu uske lekhak ke roop me apna asli naam dene me ve sakucha gaye

(Regarding prostitutes, except for condemnation, writing anything else has usually been considered as a subject to censure. Scott, in the Preface to his famous book A History of Prostitution from Antiquity to the Present Day has given the history of hesitancy in writing about this. In the year 1951, though French scholar Lecroks presented the history of the lives of prostitutes in two volumes yet he felt awkward in giving his original name as the writer of the book (Nagar, 2008).

Nagar's argument is pertinent to the main discourse of this paper as it helps to estimate the factors behind the radical digressions in the central narrative of Mrcchakatikam while conceiving Utsav. Shashi Kapoor, being a theatre lover, took the story of Utsav with great zeal and made an ambitious film project out of it that incurred him a big commercial loss. The film was concocted and directed by popular Indian dramatist Girish Karnad, who also wrote the script of the film with Krishna Basrur. This film, based on the Sanskrit play Mrcchakatikam, was conceived by Girish Karnad as early as 1974 when he was the director of the Film and Television Institute in Pune. To be produced in French by a French director, the film was in its incubation phase for almost a decade but finally Shashi Kapoor helmed the charge of producing the film in Hindi as well as in English. A big budget film, it was released simultaneously for the Indian and international market (Akhlujkar, 2007, p.76). The cinematic presentation of a story is inherently different from its presentation in the verbal form. George Bluestone in this regard says, "Hamlet can be grasped by an audience in a reading from the lectern, the actors immaculate in evening clothes; Thomas Wolfe can affect us in our own silent reading or in Charles Laughton's recitation. Both have existences apart from stage space, apart from vision, even. But can anyone imagine Caligari or the Marx Brothers apart from the filmic space which embodies them?" (1957, p. 49). This difference between these forms sometimes causes an exigency to incorporate some thematic deviations, but the change in the end of a story changes the whole purpose of the story. Karnad's intention of changing the title of the story in its adoption is not pointless instead he fully justifies the title rendered to the film by effecting desired modifications in the story to change its orientation. But the digressions that the film screens are also the indicators of change that Indian society underwent since the time of Südraka. The film presents a courtesan of Sūdraka's days named Vasantasenā as a modern-day sex-worker who is denied rehabilitation by the so-called modern society despite the existing rules framed for the protection of the rights of women. Vasantasenā of Sūdraka's days was a courtesan, who was holding her own respectable social status. Arthur William Ryder, talking about the condition of courtesans in classical India, says, "The courtezan class in India corresponded roughly to the hetaerae of ancient Greece or the geishas of Japan; it was possible to be a courtezan and retain one's self-respect. Yet the inherited way of life proves distasteful to Vasantasenā; her one desire is to escape its limitations and its dangers by becoming a legal wife" (Ryder, 1905, pp. 20-21). Here, Ryder's remark effectively embarks upon the long-cherished dream of Vasantasenā to be a wedded wife whose position has 
social sanction and respect. But the truth of a societal set up in India is that there is no exit for a woman/girl from the world of courtesans for it's a one-way lane from which there is no return. It is rare to find an example where a woman choses to be a courtesan instead she is coerced to be in this business by the society directly or indirectly, but when she seeks to return to the world of a woman where she can claim equality with her male counterpart in all aspects of life, she doesn't find an exit door from it as that door was never installed in that impenetrable walls of the world of a courtesan by the society.

The failure of the government in rehabilitation is reflected in the high re-trafficking rate. A study found that $17.5 \%$ of rescued trafficking victims had been rescued once earlier, $1.8 \%$ rescued twice before, and $6.6 \%$ rescued more than twice. It was also found that more than $57.5 \%$ had been arrested earlier. Without proper rehabilitation, it was observed that they have no option but to return to the brothels. The failure to arrest those involved with exploitation in brothels is highlighted by the fact that $34.5 \%$ of brothel owners have never faced by police during the law preceding and $54.5 \%$ of them had avoided arrest by bribing police officials. (Sujatha, 65)

So, the role of society remains pertinent in allowing and facilitating rehabilitation to a prostitute or courtesan. The Mrcchakațika of Sūdraka, basically, is a heroine centric play, where hero's role is quite subsidiary, and so is the case with the film. A careful analysis of other courtesan-based movies or any other literary piece suggests that in such works we will find that the hero gets a marginalized role to play as the heroine alone dominates the work showing more masculinity than the masculine gendered hero. But here again her masculine character is not appreciated as it doesn't support the traditional societal notion of feminity where a woman's behaviour is considered as decent only if she accepts the role assigned to her. Remaining to be a courtesan can hardly be desirable to any woman if there is chance for her to lead a respectable life unlike many wives who suffer ostentatiously in the hands of their husbands. The factor that distinguishes Sundraka's play from many other heroine centric plays of the time is that his heroine is a courtesan, who finally secures what she yearns for i.e. the status of a wedded wife but the film made 2300 years later could not accord this status to her. It, certainly, is not because the filmmakers denied it, but it was because they were convinced that the audience wouldn't accept the marriage of a courtesan with a respected person of the society. The existing social set-up didn't allow it; the deteriorated status of courtesans could be understood from the scornful expression of Nati on the mention of the word 'courtesan'. The difference between the two times is very clearly mentioned by the Sūtradhāra (narrator) in the beginning itself of the film, where he announces the fact that the story is not of this India, he says, "Ye us yug ki kathā hai, jab samāja me veśyāon kā ādar hotā thā; unkā ek apnā sthān thā," [This is the story of that era when courtesans were respected in the society, they had their own place], on which Națī says, yāni āj ke Bhārata kī nahī [means, not of today's India], Sūtradhāra further says, "Nahin"[ means, no] (Kapoor, 1984).

The paper analyses both the works on the comparative scale keeping in view the gender issues and depiction of female characters in these works. Further, on the basis of the approaches and biases of the writers, the paper explores to understand the social milieu of the time. In the play, the role of Cārudatta's wife is not much detailed upon as she appears at certain places physically and at some places just through the mention of her name by her maid Radanikā, and her husband's friend Maitreya. Her character in the play appears as 'Vadhū'; the author chooses to depict her more as Cārudatta's wife than an individual, therefore, he prefers to mostly use common noun in place of proper noun for her making her insignificant to the narrative. For the 
first time, she appears physically towards the end of the third act when her name is being called by Radanikā in the context of gold ornaments being stolen. However, in the movie, her role is a prolonged one with a character curated to be powerful. Here, she herself overhears Cārudatta regretting the loss of gold ornaments. When Radanikā, in the play, informs Dhutā about the theft of the gold from Cārudatta and Maitreya, she worriedly asks Radanikā, whether her husband and his friend are safe or not? Having been assured of their safety, she further says that had her husband been injured in body it would have been better than the injury in character that was going to be caused on account of the loss of gold entrusted to the poor. While Aditi, in the film, who herself witnessed the event, taunts her husband saying, "Tum sab, sāre purușa ek jaise ho, strī dekhi ki lār țapakā." [You all, all men are alike, as soon as you see a woman, your saliva starts dripping] Having taunted thus, infuriated Aditi calls Maitreya, and says, "Ye lïjiye na! Pita-jī ke diye huye gahano me se bas yahī ek mālā bachi huyi hai, ise de dījiye Vasantasenā ko, kehnā hame kṣamā kare, jo kuch bhī huā, usme kisī ka doṣa nahi." [Please take this, this is the only necklace left in father's jewels, give it to Vasantasenā, and tell her to forgive us as no one can be held responsible for what happened] (Kapoor, 1984). She then leaves for her father's house in the midnight itself. If we compare her dialogues of this occasion in both the works, we'll notice another significant point that in the play Dhūtā says that the necklace was from her mother's house, while Aditi considers the necklace to be from her father's house. It again points out the importance of women in two time periods.

Another important character of the movie is Vasantasenā's mother, who appears in the act the fourth of the play for the first time asking Vasantasenā to take bath to worship the Gods. She is depicted to be such a nice woman in the play who during the trial of Cārudatta as an accused for the murder of Vasantasenā was asked to reveal the truth about where Vasantasenā was, and there she utters the name of Cārudatta appreciating him as man of the highest merits, with whom her daughter was enjoying her youth. When Samsthānaka forces her to recognize the casket of ornament to prove Cārudatta the convict she drives him away calling him scoundrel. The ornaments recovered from Cārudatta's house were enough to prove him the culprit in her eyes still; she doesn't accuse him and prays for him in the court saying, "prasīdantu prasīdantvāryamiśrāḥ. Tadyadi vyāpāditā mam dārikā vyāpāditā. Jīvatu me dīrghāyuḥ. anyacca. arthipratyarthinorvyavahārah. ahamarthinī. tanmuñcataitam" (Kale, 2017, p.346). She pleads to the judge and people present there to show mercy on Cārudatta and spare him to live long, and this plea from her was on behalf of the mother of the murdered (being complainant). But in the movie, her character is completely altered and she is presented to be a typical brothel house runner, who doesn't even have mercy for her own child. It is shown in the film that Samsthānaka visits Vasantasenā's mother when she had gone to Cārudatta and shows his anger becoming violent and hurts his own hands. Here she is shown to be just money minded female who is more interested in her customer than her own daughter. She advises him on how to win a lady like Vasantasenā, and then devises a plan for him to meet Vasantasenā saying, "kal subere āp ek dhakī huyī gādī bhej dījiye, aur āp Puṣkar Van me uski pratikṣā kerna, kal Vasanta utsava hai na, mai sajā, dhajā ker Vasantasenā ko āpke pās bhej dūngi, phir āp jāne aur vo." [You send a veiled carriage tomorrow morning and wait in Puṣkar Van for her, it is Vasant Utsav tomorrow, so I'll adorn Vasantasenā and send her to you, then it will be between you and her] (Kapoor, 1984). This depiction of Vasantasenā's mother shows the approach of the contemporary society towards a woman who is not accepted in the mainstream, and is forced to live condemned in the world, she despises.

Madanikā, Vasantasenā's maid, is another significant character of the play, who in the film is shown to be one among the many prostitutes. She loves Sarvilaka, who in the film is depicted as 
Sajjal. Sajjal should have been the replica of Śarvilaka, but his character also is changed substantially to support more significant shifts in the movie. Madanikā is maid servant of Vasantasenā, whose background is created in the film as a slave who was bought as a small child paying lot of gold by Vasantasenā's mother. Informing this to Sajjal, who loves her and wants to marry her, Madanikā tells him about the price of her freedom that can be bought only by paying a large amount of gold to Vasantasenā's mother, to which he agrees immediately and commits that theft at Cārudatta's house. Sajjal in the movie is widely acclaimed thief, while Sarvilaka, in the play, repents over the act of theft when he commits it at Cārudatta's house. He regrets it thinking of his unblemished Brahmin family, and says,

“...Dhik! Kṛtamandhakāram! atha vā mayāapyasmadbrāhmạ̣ akule dhik Kṛtamandhakāram. Aham hi caturvedavidoapratigrāhakasya putraḥ Śarvilako nāma Brāhmaṇo gaṇikāmadanikārthamakāryamanutiṣṭhāmi. Idānim karomi Brāhmañasya prañayam" (Kale, 2017, p.118).

The same has been reclaimed by Madanikā saying, "Śarvilaka akhañditacāritroasi. tanna khalutvayā mama kārañātsāhasam kurvatāatyantaviruddham-ācaritam” (Kale, p. 140). Stating that he was having unblemished character but spoilt it by committing the theft for her. Here he, unlike Sajjal, has been presented to be a poor Brahmin of greater character who commits the theft just for his love for Madanikā for the first time. Another subtle point can be noted here that his character was not blemished or going to be blemished by the society for being in love with a courtesan or by marrying her but theft is considered a greater crime. In both the works Madanikā recognizes the ornaments and suggests him to disguise as a servant of Cārudatta, and returns them to Vasantasenā on his behalf which Vasantasenā comes to know before he appears in front of her with the ornaments, and without letting them (Sajjal and Madanikā) know that she knew about the failure of their plan, she gives Madanikā as a gift to Sajjal out of happiness saying, "ye meri oar se tumhe puraskāra, àja tak ye meri dāsī rahī ab se ye tumhārī jīvana sangīnī”, [this is a gift to you from me, she has been my slave till date, now she'll be your soulmate] my side here she also expresses her own emotions to attain the same status that Madanikā attained, and adds further "jāo sukhī raho, āja mujhe tumse īrșyā ho rahī hai." [go and be happy, today I feel envious to you] But in the play, her rehabilitation is different from the movie as has already been noticed that Sajjal is a thief by profession, she goes to a thief whose own social status is at stake because of his profession. In the play, when Vasantasenā herself overhears their conversation, and comes to know about Sarvilaka's scheme and its failure, she, being impressed with their love and honesty, decides to give Madanikā to Śarvilaka, and considers her vandanīyā on account of her marriage with a man of noble birth, saying, "Sāmpratam tvameva vandanīyā samvṛtā. tadgaccha. āroha pravahanam. smarasi mām” means, now you yourself have become worthy of salutation. So, go and ascend the cart. And remember me. (Kale, p.152)

Coming back to Vasantasenā's relation with Cārudatta in the play and film, we find that the film from beginning to end shows far more intense relation between the two. When Vasantasenā visits Cārudatta to inform him about getting her ornaments back from the thief himself for freeing him from any kind of worry, the film shows, just to appeal to the senses of the audience, another physical union of Cārudatta and Vasantasenā, without caring for its results that makes the audience expect their union more in the end, while finally she was to just surrender her to her fate that was going to remain unchanged. Here again, Aditi reappears to play even more crucial role, she enters the room just after Cārudatta leaves on which Vasantasenā, having taken by surprise, asks "Kaun ho tum? Koi dāsi?" (who are you? some slave?) on this the woman replies, "nahin, unki patnī, caliye nahā lījiye candana kā lepa taiyar hai, kṣamā karein hamāre ghar me 
āpke śrnngār lāyak koi sāmagri nahi.” [No, I am his wife, come and have bath, the sandalwood paste is ready, I seek your forgiveness as there is nothing suitable for your makeup at our house]. On Vasantasenā's questions “āpa krodhita nahi huyī mujhe dekhkar?" [Didn't you get angry on seeing me?) she says "nahi" [No] (Kapoor, 1984). Further, in the movie it was Aditi who adorns Vasantasenā happily. Here, Cārudatta's son comes to her asking "bāhar jāun khelne ke liye" [Shall I go out to play] (Kapoor, 1984) she allows him giving him the clay cart saying "tumhe gādī cāhiye thi na” ye lo, sundar hai nā?” [you wanted a cart, didn't you? Take this, isn't it beautiful?] (Kapoor, 1984) then Vasantasenā calls him, but he doesn't come, and then Aditi introduces her to Rohit saying "jānte ho ye kaun hain, ye bhi tumhāri mā hain." [Do you know who she is? She also is your mother] (Kapoor, 1984). To his question on her ornaments, she removes all of them and then asks him "ab to mai tumhāri mā jaisī lagatī hūn, na?" [Now, I look like your mother, don't I?] (Kapoor, 1984) and puts all her ornaments in his clay cart to make it golden one, on which Rohit kisses her. Vasantasenā's desire to win Cārudatta, who also loves her, is immense for which she is ready to leave anything, but still she is denied that, and is left for Samsthanaka, who, for this reason, is shown to be less villainous and less despicable than he actually is in the play. In the movie, he doesn't kill Vasantasenā intentionally, instead he wails for her and blames Cārudatta as the cause of his anger, and finally accuses him as the murderer out of envy. While in the play, he is depicted to be a fool and villain, who out of anger, asks his servants to murder her when they deny, he himself murders her, and puts the blame on Cārudatta. His villainy seems to be dominating in the movie when he is impatient to see Cārudatta dying, but meanwhile Vasantasenā, having been saved by the monk, reaches there and entreats the executioners to leave him as she was alive. Despite such turn of events, they reject her request saying that in order of the King, Cārudatta is accused of the murder of a prostitute "Veśyā ki hatyā kā danḍa" [punishment for the murder of a courtesan] (Kapoor, 1984) to which both Aditi and Vasantasenā shout that it is Vasantasenā who is addressed as 'veśyā' in the order; but still they were going to kill Cārudatta when another messenger comes announcing that the autocrat, the unjust king Palak has been killed by the new king Âryaka, who has forgiven all the accused. Having been spared, Cārudatta goes and hugs his wife which Vasantasenā looks at with desperate eyes, and feels to be more desolate, goes back home crying. After a while Cārudatta asks his wife "Vasantasenā kahān hai?" [Where is Vasantasenā?] (Kapoor, 1984). His wife says, "Chalo ghar chalein, Rohit ro rahā hogā" [Let's go home, Rohit would be crying] (Kapoor, 1984) and Cārudatta agrees to it. Madanikā also goes with Sajjal happily. But the film ends on a sad note showing Samsthānaka in front of Vasantasenā's house crying and calling upon her name on which Vasantasenā appears who supports fallen Samsthānaka at her door and takes him in. In the play, Vasantasenā wins the person whom she loved and who also loved her. Also, Vasantasenā says in the end, "ārya kṛtārthāsmi" [my wishes have been fulfilled, sir]. (Kale, 2017, p. 402). On listening to Śarvilaka's words, "ārye Vasantasene paritușto Rājā bhavatīm vadhūśabdenānugrhniāti." that the King had bestowed upon her the title of wedded wife (Kale, p.402). And Cārudatta says, "prāptā bhūyaḥ priyeyam priya suhṛdi bhavānsangato me vayasyo labhyam kim" I have got beloved of mine (referring to Vasantasenā), what else I need. (Kale, p. 404)

The end of the film and the play very clearly show their societal stand on Vasantasenā, as in the end, the play leaves Vasantasenā with the honour of a 'wedded wife' bestowed by the King that indicates towards her acceptance in the society which she yearns for, and moreover Cārudatta accepts her considering the best gift of the time, while in the film she is emphatically labelled as "Veshya" wherein she is cursed to be remain the same, her whole life bearing the stigma of a "fallen women" (Qureshi, p.320). The end also shows that she accepts the most hated 
person in her house to do justice to the duty of a prostitute. Finally, the paper brings to the attention of the readers that the film made in the modern era denied all that it was expected to bestow upon the deprived characters, most importantly, the solution of rehabilitation of Vasantasenā, and a prostitute, in spite of the fact that in the original story it is very much practiced and accepted. The deviations brought upon the film by its makers may also be an attempt to save the rights of another woman whose depiction in the play is quite subdued while in the film this character is sketched very prominently, but still in the name of Aditi, who is not insecure in considering Vasantasenā as a beloved of her husband should be open to accept her as another wife of her husband as she also introduces her to her son as 'another mother of his'. And even Vasantasenā in the play from very beginning knows that Cārudatta is married and has a son, so the thought of being a rival or co-wife would have been there on her mind since then (Limaye and Price, 2010, p. 166). One is clear that while the films have categorically adopted a regressive mode, novels such as Requiem in Raga Janki and My Name is Gauhar Jaan have made conscious efforts to generate consciousness about rich cultures of baijis and tawaifs, which is otherwise homogenized and garbed without considering the finer nuances of this profession, primarily due to the impact of colonial power on courtesan culture (Das and Tripathi, p. 213).

\section{References:}

Aklujkar, V. (2007). Mrcchakatikam to Utsav: Re-creation of a Sanskrit Classic by Girish Karnad. In H. R. Pauwels (Ed.), Indian Literature and Popular Cinema: Recasting Classics (pp. 76-96). London Routledge.

Bluestone, George. (1957). “"Madame Bovary” in Book and Film”, The Tulane Drama Review (The MIT Press), vol. 1, No. 3, pp. 49-61.

Chandra, Moti (1973). The World of Courtesan: Sensuous Women who practiced Love as an Art and Profession. Hind Pocket Books.

Das, Chhandita and Priyanka Tripathi (2020). "Recontextualizing the Lives of Courtesans in Neelum Saran Gour's Requiem in Raga Janki and Vikram Sampath's My Name is Gauhar Jaan”, Indian Literature (Sahitya Akademi), vol. 64, pp. 204-215.

https://doi.org/10.4324/9780203933299

Kale, M. R. (Ed.). (2017). The Mrcchakațika of Sudrak. New Delhi: Motilal Banarasidass Publishers.

Kapoor, S (Producer) \& Karnad, G. (Director). (1984). Utsav. (Motion Picture). Bangalore: Eagle.

Limaye, Mohan R. and Kim Price. (2010). “"The Little Clay Cart (Mrcchakatika)”: The Construction of Gender and Emotion in Act V, “The Storm"”. Indian Literature (Sahitya Akademi), vol. 54, pp. 162-176.

Nagar, A. (2008). Ye Kothevaliyan. Allahabad: Lokbharati.

Qureshi, Regula Burckhardt (2006). "Female Agency and Patrilineal Constraints: Situating Courtesans in Twentieth-Century India.” The Courtesan's Arts: Cross-Cultural Perspectives, edited by Martha Feldman and Bonnie Gordon, Oxford University Press.

Súdraka. (1905). The Little Clay Cart: A Hindu Drama (A. W. Ryder, Trans.). Cambridge, Massachusetts: Harvard University Press.

Sujatha, M (2018) A Study on Psycho social Condition of the Parents of Sex trafficked Female Victims, https://sg.inflibnet.ac.in/bitstream/10603/258524/9/o9_chapter\%202.pdf. 
Tripathi, Priyanka and Chhandita Das (2020). "Social Distancing and Sex Workers in India”, Economic and Political Weekly, vol. 55, no 31, pp. 21-23.

Tula, Meenal and Rekha Pande (2014). "Re-Inscribing the Indian Courtesan: A Genealogical Approach". Journal of International Women's Studies, vol. 15, no. 1, pp. 67-82. 